\title{
A Novel Fungal Metabolite NG-061 Enhances and Mimics Neurotrophic Effect of Nerve Growth Factor (NGF) on Neurite Outgrowth in PC12 Cells
}

\author{
Mayumi Ito, Noriyoshi Sakai, Kyoko Ito, Fumio Mizobe, \\ KazUnORi Hanada and Kazutoshi MizouE* \\ Research Laboratories, Taisho Pharmaceutical Co., Ltd., \\ 1-403, Yoshino-cho, Omiya-shi, Saitama 330-8530, Japan \\ Renuka Bhandari, Tadashi Eguchi ${ }^{\dagger}$ and Katsumi Kakinuma \\ Department of Chemistry, and Department of Chemistry and Materials Science ${ }^{\dagger}$, \\ Tokyo Institute of Technology, \\ O-okayama, Meguro-ku, Tokyo 152-8551, Japan \\ (Received for publication December 15, 1998)
}

\begin{abstract}
During the course of our screening program for low molecular natural products with their ability to potentiate and /or mimic neurotrophic effect of NGF, a novel fungal metabolite, phenylacetic acid hydrazide derivative NG-061 was isolated from the fermentation broth of Penicillium minioluteum F-4627. NG-061 enhanced and mimicked neurotrophic effect of NGF on neurite outgrowth in a rat pheochromocytoma cell line PC12.
\end{abstract}

Nerve growth factor (NGF) is a polypeptide originally purified from mouse submaxillary gland as a prototypical neurotrophic factor essential for growth and development of neurons in the central as well as peripheral nervous system ${ }^{1,2)}$. Survival and growth of cultured neuronal cells are also affected by such biological polypeptides as fibroblast growth factor. These neurotrophic factors have been shown to protect against neuronal dysfunction and death in vivo in animal models of injury and neurologic disease. It was reported that NGF treatment could ameliorate age-related impairment in memory test and prevent lesion-induced loss of septal cholinergic neurons in rats ${ }^{3 \sim 5}$. Also it is known that NGF can prevent neuronal loss of the hippocampus in the cerebral ischemia model in the Mongolian gerbil ${ }^{6)}$. These findings suggest that NGF can be effective for treatment of the dementia and the cerebral paralysis. However, it is very difficult to use NGF as a therapeutic agent since it must be administered intraventricularly because of impermeability of large molecule cross the blood-brain barrier. These observations rationalize the idea that low molecular compounds exhibiting and/or enhancing neurotrophic actions can be developed as promising therapeutic drugs to prevent neuronal cell death.

From this point of view, we started to explore low molecular natural products with their ability to mimic and/or potentiate NGF by peripheral administration. It is well known that the PC12 cell line, derived from rat pheochromocytoma cells, responds to NGF to differentiate into neuron-like cells with elongated outgrowth $^{1,2,7)}$. We have utilized this property of the PC12 cell line in the screening and the purification of compounds exhibiting NGF-like actions and enhancing neurotrophic effects of NGF from the microbial metabolites ${ }^{8 \sim 11)}$. In our screening program, a fermentation broth of Penicillium minioluteum F-4627 was found to enhance neurite outgrowth in $\mathrm{PC} 12$ cells in the presence of NGF. Bioassay-guided fractionations of the ethyl acetate extract of the culture broth Penicillium minioluteum F-4627 led to the isolation of a novel compound NG-061. The structure of NG-061 was determined by spectroscopic analysis and X-ray diffraction method as shown in Fig. 1. In this paper, we 
Fig. 1. Structure of NG-061.

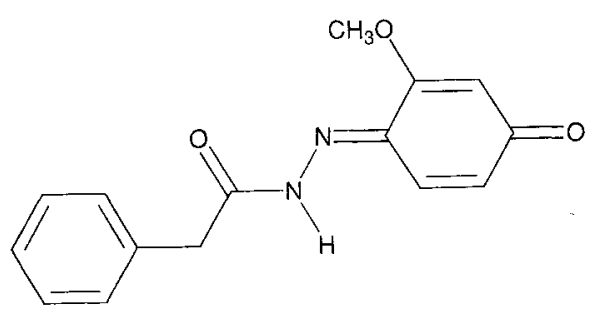

wish to describe the taxonomy of the producing organism, isolation, and physico-chemical and biological properties of NG-061.

\section{Results and Discussion}

\section{Taxonomy of the Producing Organism}

On all agar media except for Sabouraud agar the colonies grew well and the spore formation was good whereas the growth and the spore formation were moderate on Sabouraud agar. Colonies on all agar media except for Sabouraud agar attained a diameter of $38 \sim 40 \mathrm{~mm}$ and were felty to velvetinous, grayish yellow to grayish yellow green in color. Colonies on Sabouraud agar attained a diameter of $25 \mathrm{~mm}$ and were grayish green, and grayish yellow to light red at the center in color. Slightly pale reddish soluble pigment was produced in malt extract agar and Sabouraud agar. The reverse sides on all agar media were grayish yellow green to light brown, and pale reddish at the center.

The hyphae possessed septa, presented white to partially yellow color and branched abundantly. The conidia were verticillately and separately formed through metulae on the tip of the conidiophores, which branched and arose up from the basal or aerial hyphae, and also penicilli, morophologically characteristic of the genus Penicillium were observed. The conidiophores had septa, and were mostly smooth and sometimes rough in a part on the surface. The size was $3 \sim 4 \mu \mathrm{m}$ in diameter and $100 \sim 200 \mu \mathrm{m}$ in length. The five or six metulae verticillated symmetrically and adhered closely to each other from the tip of the conidiophores. On the same tip the phialides verticillated. The metulae were smooth on the surface and $10 \sim 14 \mu \mathrm{m} \times 2 \sim 3 \mu \mathrm{m}$ in size. The features of conidia were globose to subglobose and smooth on the surface with $2 \sim 4 \mu \mathrm{m} \times 2 \sim 3 \mu \mathrm{m}$ in size. When the cultivation was prolonged for more three weeks, the formation of sexual spores was not recognized.

The optimal temperature for the growth was 26 to $36^{\circ} \mathrm{C}$, and the optimal $\mathrm{pH}$ was 3 to 7 in $\mathrm{YpSs}$ liquid medium. Comparison of data of Penicillium reported by RAPER, et al. ${ }^{12)}$ and J. I. PITT ${ }^{13)}$ with those of the strain F-4627 strongly suggested that the strain F-4627 very resembled to Penicillium minioluteum. Therefore, the strain F-4627 was designated as Penicillium minioluteum F-4627.

This strain was deposited at the National Institute of Bioscience and Human-Technology, Agency of Industrial Science and Technology, Ministry of International Trade and Industry, Tsukuba-shi, Japan as the accession No. FERM P-11648.

\section{Fermentation}

A loopful of Penicillium minioluteum F-4627 from a slant culture was inoculated into a 500-ml Erlenmeyer flask containing $100 \mathrm{ml}$ of a seed medium consisting of glucose $2 \%$, polypepton $0.5 \%$, yeast extract $0.2 \%$, $\mathrm{KH}_{2} \mathrm{PO}_{4} 0.1 \%$ and $\mathrm{MgSO}_{4} \cdot 7 \mathrm{H}_{2} \mathrm{O} 0.05 \%$ at $\mathrm{pH}$ 6.0. The flask was shaken on a rotary shaker at $28^{\circ} \mathrm{C}$ for 72 hours. Three hundred $\mathrm{ml}$ of the seed culture was transferred into a 50-liter jar fermenter containing 30 liter of a production medium with the same composition as in the seed medium. Fermentation was carried out at $28^{\circ} \mathrm{C}$ for 48 hours under aeration of $1.0 \mathrm{v} / \mathrm{v} /$ minute and agitation of $400 \mathrm{rpm}$.

\section{Isolation}

All fractionations were guided by bioassay of potentiation of NGF-mediated neurite outgrowth in PC12 cells. The isolation procedure of NG-061 is shown in Fig. 2. The culture broth was centrifuged to separate mycelial cake and supernatant. Extract of the mycelial cake with 3 liters of acetone was concentrated to an aqueous solution, which was combined with 25 liters of the supernatant. The aqueous solution passed through 1.5 liters of a column of Daiaion HP-20. After washing the column with water, the absorbed material was eluted with methanol and concentrated in vacuo to an aqueous solution. The aqueous solution was then extracted with 1 liter of ethyl acetate 4 times. The combined organic layer was dried over $\mathrm{Na}_{2} \mathrm{SO}_{4}$ and evaporated in vacuo to yield $8.8 \mathrm{~g}$ of a crude material. It was dissolved in $10 \mathrm{ml}$ of $\mathrm{CHCl}_{3}$ and chromatographed on a silica gel 
Fig. 2. The procedure of isolation of NG-061.

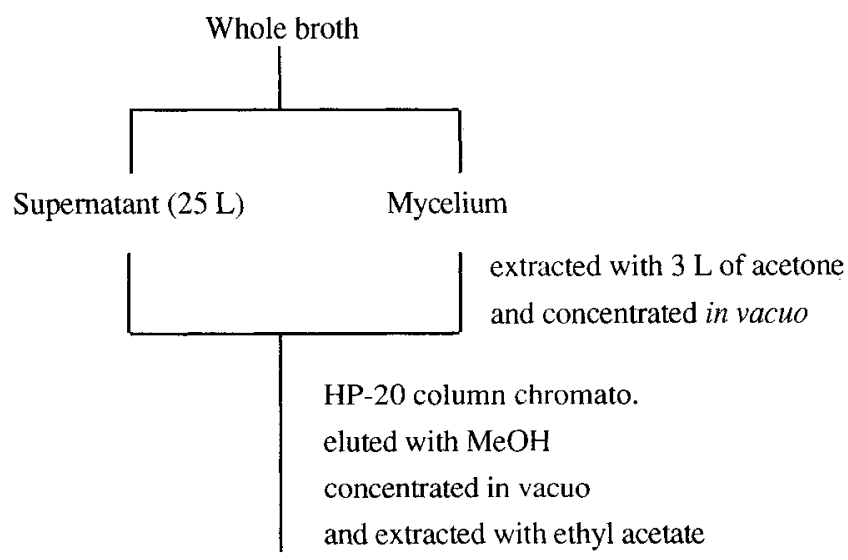

Ethyl Acetate Layer

dried over $\mathrm{Na}_{2} \mathrm{SO}_{4}$

and concentrated in vacuo

Greenish Yellow Syrup

Silica gel column chromato.

eluted with $\mathrm{CHCl}_{3}-\mathrm{MeOH}$

Active Fractions

concentrated in vacuo

HPLC over ODS eluted with $35 \% \mathrm{CH}_{3} \mathrm{CN}$ in $\mathrm{H}_{2} \mathrm{O}$

Active Fractions

concentrated in vacuo

and precipitation by $\mathrm{MeOH}$

NG-061 (41 mg) as pale yellow powder

column $(5 \times 20 \mathrm{~cm})$ using stepwise gradient of $\mathrm{CHCl}_{3}$ followed by $\mathrm{CHCl}_{3}-\mathrm{MeOH}(98: 2)$.

The active fractions were then combined, concentrated and chromatographed on HPLC using $35 \%$ acetonitrile. After evaporation to dryness, $41 \mathrm{mg}$ of NG-061 was given as a pale yellow powder by precipitation from methanol. Furthermore, NG-061 was crystallized as pale yellow needles.

\section{Physico-chemical Properties}

The physico-chemical properties of NG-061 are summarized in Table 1. It was obtained as a pale yellow needle, which was readily soluble in dimethyl sulfoxide and pyridine, soluble in methanol, ethanol and acetone, slightly soluble in ethyl acetate, diethyl ether, benzene and $n$-hexane and insoluble in water. It gave a positive color reaction to iodine, sulfuric acid, anisaldehydesulfate, but was negative to ninhydrin. The UV spectrum of NG-061 was observed with two maxima at 207 and $340 \mathrm{~nm}$ in methanol. The IR spectrum of NG-061 showed absorptions at $3438 \sim 3100 \mathrm{~cm}^{-1}$ due to a $\mathrm{OH}$ and/or NH group and two strong absorptions at 1680 and $1640 \mathrm{~cm}^{-1}$ corresponding to carbonyl groups, suggesting the existence of a ketone carbonyl and an amide moiety, respectively. The molecular formula of NG-061 was determined to be $\mathrm{C}_{15} \mathrm{H}_{14} \mathrm{~N}_{2} \mathrm{O}_{3}$ on the basis of its HREI-MS spectrum and elemental analysis as shown in Table 1. The degree of unsaturation was estimated to be 10 by its molecular formula. The ${ }^{1} \mathrm{H}$ NMR spectrum measured in dimethyl sulfoxide- $d_{6}$ showed 14 signals, consistent with its molecular formula. The ${ }^{13} \mathrm{C}$ and ${ }^{1} \mathrm{H}$ 
Table 1. Physico-chemical properties of NG-061.

\begin{tabular}{ll}
\hline Appearance & Pale Yellow crystal \\
Melting Point & $189-190^{\circ} \mathrm{C}$ \\
Elemental Analysis & \\
$\quad$ Found $(\%)$ & C: $66.66, \mathrm{H}: 5.22, \mathrm{~N}: 10.36$ \\
$\quad$ Calcd. for $\mathrm{C}_{15} \mathrm{H}_{14} \mathrm{~N}_{2} \mathrm{O}_{3}(\%)$ & $\mathrm{C}: 66.19, \mathrm{H}: 5.14, \mathrm{~N}: 10.30$ \\
EI-MS $(m / z)$ & $270\left(\mathrm{M}^{+}\right)$ \\
FAB-MS $(m / z)$ & $271\left(\mathrm{M}^{+}+1\right)$ \\
HR-EIMS $(m / z)$ & \\
Found & 270.1002 \\
Calcd. for $\mathrm{C}_{15} \mathrm{H}_{14} \mathrm{~N}_{2} \mathrm{O}_{3}$ & 270.1004 \\
Molecular Formula & $\mathrm{C}_{15} \mathrm{H}_{14} \mathrm{~N}_{2} \mathrm{O}_{3}$ \\
UV $\lambda_{\max } \mathrm{nm}(\varepsilon)$ in methanol & $207(15,100), 340(30,300)$ \\
IR $v_{\text {max }} \mathrm{cm}-1(\mathrm{KBr})$ & $3438,3111,1680,1640,1569,1543$ \\
TLC $(\mathrm{Rf})$ & $0.21,{ }^{\mathrm{a}} 0.70, \mathrm{~b} 0.49 \mathrm{c}$ \\
\hline
\end{tabular}

a) Merck, Kieselgel $60 \mathrm{~F}_{254}$ : benzene-acetone (5:1).

b) Merck, Kieselgel $60 \mathrm{~F}_{254}: \mathrm{CHCl}_{3}-\mathrm{MeOH}(10: 1)$.

c) Merck, HPTLC RP- $18 \mathrm{~F}_{254}: 60 \% \mathrm{CH}_{3} \mathrm{CN}$ in $\mathrm{H}_{2} \mathrm{O}$.

Fig. 3. ${ }^{1} \mathrm{H}$ NMR spectrum of NG-061 in DMSO- $d_{6}$.

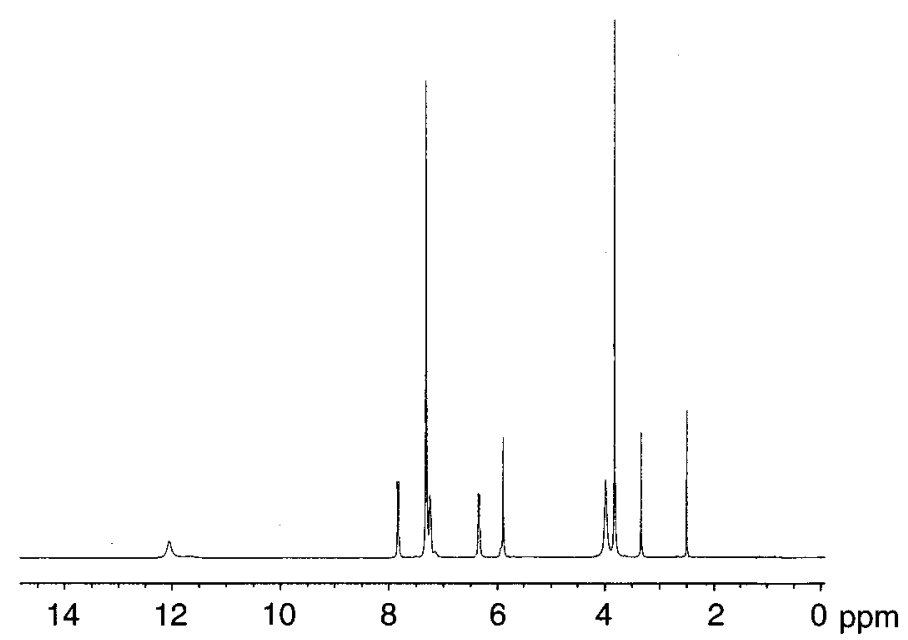

NMR spectra in dimethyl sulfoxide- $d_{6}$ were shown in Fig. 3 and 4. The structure of NG-061 was elucidated by means of spectroscopic analysis and $\mathrm{X}$-ray diffraction method as described in the accompanying paper ${ }^{14)}$ as shown in Fig. 1. 
Fig. 4. ${ }^{13} \mathrm{C}$ NMR spectrum of NG-061 in DMSO- $d_{6}$.

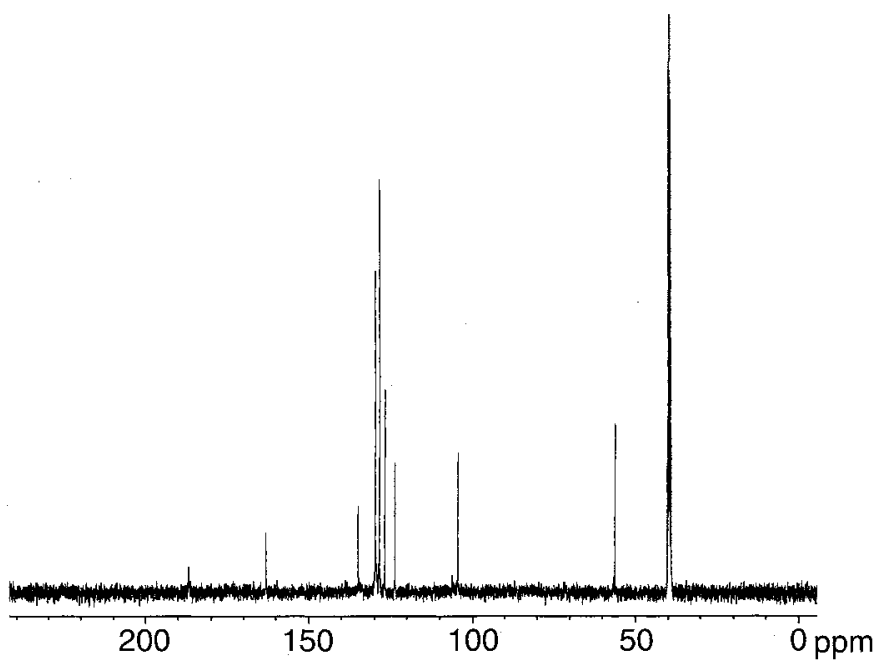

Fig. 5. Effect of NG-061 on neurite outgrowth in $\mathrm{PC} 12$ cells.

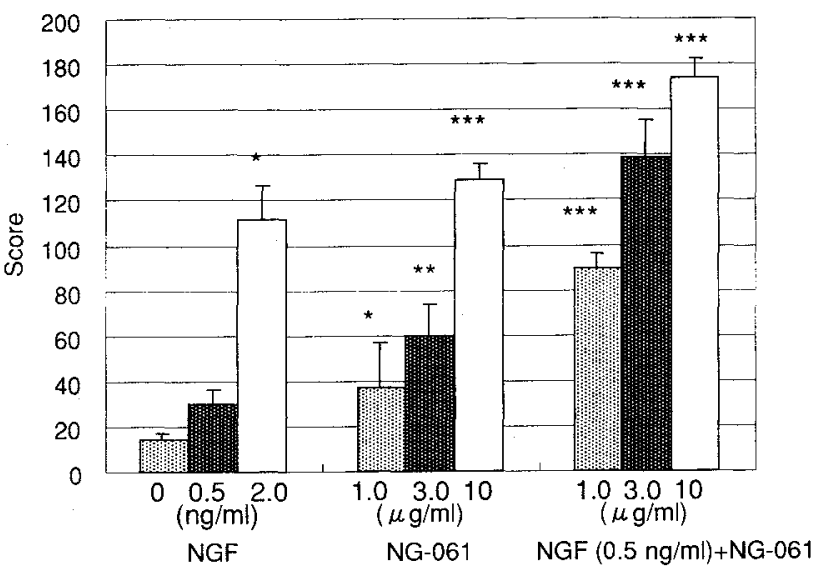

Significantly different from control: $* p<0.05$; ** $P<0.01 ; * * * P<0.001$ ( $t$-test).

\section{Biological Properties}

Neurotrophic effect of NG-061 on PC12 cells is shown in Fig. 5. NG-061 induced neurite outgrowth in PC12 cells at doses of $1 \sim 10 \mu \mathrm{g} / \mathrm{ml}$. The maximal effect was similar in magnitude to that of NGF at $10 \mathrm{ng} / \mathrm{ml}$. Neurite outgrowth induced by NG-061 was more effective in the presence of low dose of NGF as shown in Fig. 5. The
Table 2. Effect of NG-061 on cell survival in primary neuronal culture.

\begin{tabular}{ccc}
\hline & \multicolumn{2}{c}{ Neuronal Survival } \\
\hline & Hypoxic-stress & Non-treatment \\
\cline { 2 - 3 } Concentration & $\%$ of control & $\%$ of control \\
\hline Control & 100 & 100 \\
$3 \mu \mathrm{g} / \mathrm{ml}$ & 111 & 106 \\
$10 \mu \mathrm{g} / \mathrm{ml}$ & 103 & 101 \\
\hline
\end{tabular}

maximal effect was similar in magnitude to that of NGF at $50 \mathrm{ng} / \mathrm{ml}$. NG-061 showed no protective effect on mouse cerebral cortical neurons in the cell survival assay system (Table 2). NG-061 has no antimicrobial activities against selected bacteria, fungi and yeast tested by the conventional paper disc method at a concentration of $1 \mathrm{mg} / \mathrm{ml}$ (data not shown).

NG-061 demonstrated neurotrophic effect and induced neurite outgrowth in $\mathrm{PCl} 2$ cells whereas it showed no protective and survival effects on hypoxic stress in the primary culture of mouse cerebral cortical neuron. NG-061 is likely to work specifically for PC12 cells. The detailed mode of action is now under study. 


\section{Experimental}

\section{General}

Melting point was determined with a Yanagimoto micro-melting point apparatus and was uncorrected. Optical rotation was measured on a Jasco DIP-360 polarimeter in a $10 \mathrm{~cm}$ tube. IR spectrum was recorded on a Perkin-Elmer 1760 FT-IR spectrophotometer. UV spectrum was measured on a Hitachi 220A spectrophotometer. EI-MS, FAB-MS and HREI-MS spectra were determined with a Jeol JMX-SX 102 mass spectrometer. NMR spectra were obtained with a Jeol JNM-GX400 using the solvent peaks as an internal reference downfield of TMS at $0 \mathrm{ppm}$.

\section{HPLC}

Preparative HPLC separation was performed with monitoring the absorbance at $340 \mathrm{~nm}$ using a SenshuPak ODS column (ODS-4251-N, $10 \mathrm{~mm} \times 25 \mathrm{~cm}$ ) with a Waters Model $600 \mathrm{E}$ system, maintained at $50^{\circ} \mathrm{C}$ with $35 \%$ acetonitrile solution at flow rate of $4.6 \mathrm{ml} /$ minute.

\section{Taxonomy Study}

The strain F-4627 was isolated from a dead leaf collected at Niigata City in Japan. To microscopically examine the cultural properties, the strain F-4627 was incubated for 14 days at $26^{\circ} \mathrm{C}$ using malt extract agar, potato glucose agar, Czapek agar, Sabouroad agar, oatmeal agar and YpSs agar media. The morphological observations of the colonies formed on malt - extract agar for 7 days at $25^{\circ} \mathrm{C}$ were performed under a optical microscope. The optimal temperature and $\mathrm{pH}$ for the growth of the strain F-4627 were examined in YpSs liquid medium.

\section{Assay for Neurotrophic Activity in PC12 Cells}

$\mathrm{PC} 12$ cells were obtained from RIKEN Cell Bank and maintained as monolayer culture in DULBECCO's modified EAGLE's medium (DMEM, GIBCO) with 10\% heatinactivated fetal bovine serum (FBS), 5\% horse serum (HS) $50 \mathrm{U}$ penicillin $\mathrm{G}$ and $50 \mu \mathrm{g} / \mathrm{ml}$ streptomycin. The cells were kept in a humidified incubator at $37^{\circ} \mathrm{C}$ and $5 \% \mathrm{CO}_{2}$. The cells were plated on collagen-coated 24-well plates (Corning) at a density of $1 \times 10^{4}$ per well. After 24 hours of culture, the medium was changed to the medium containing a test compound for evaluation of neurotrophic activity. For assay of enhancement of NGF, NG-061 at the indicated concentration was added to the medium in the presence of $0.5 \mathrm{ng} / \mathrm{ml}$ of NGF. And the cells were further incubated for 48 hours. To evaluate activity, 100 cells were observed under a phase-contrast microscope with scoring (round cells: 0 , morphologically changed cells without neurite: 1, cells with neurites shorter than the diameter of the cell body: 2 , cells with neurites longer than the diameter of the cell body: 3 ). One hundred cells were scored from a randomly chosen field and this was repeated 3 times ( 300 cells scored in total).

Neuronal Cell Preparation and Cell Survival Assay

The primary culture of cerebral cortical neurons was prepared from 18-day-old Wistar rat embryos. Dissociated neuronal cells in a $1: 1$ mixture of DMEM and HAM'S F12 medium containing with $10 \%$ heatinactivated FBS, $100 \mathrm{U} / \mathrm{ml}$ penicillin, and $100 \mu \mathrm{g} / \mathrm{ml}$ streptomycin (DF-FBS medium) were plated on 24-well plates coated with polyethlenimine at $1 \times 10^{5} \mathrm{cells} / \mathrm{cm}^{2}$ and incubated at $37^{\circ} \mathrm{C}$ in a humidified $5 \% \quad \mathrm{CO}_{2}$ incubator (day 0 ). On day 1 , the medium was changed to a serum-free DF medium supplemented with $5 \mu \mathrm{g} / \mathrm{ml}$ transferin, $5 \mu \mathrm{g} / \mathrm{ml}$ insulin, and $20 \mu \mathrm{m}$ progesterone (DF-TIP medium) in the presence of a test compound and further incubated for 5 days. On day 4, hypoxic stress was given by incubating the culture for 4 hours in a humidified atmosphere of $1 \% \mathrm{O}_{2}-5 \% \mathrm{CO}_{2}$ in $\mathrm{N}_{2}$, and these cells were further cultured for 48 hours in $5 \% \mathrm{CO}_{2}$ in air. The effect of a test compound on the neuronal cells was evaluated by the activities of neuronal survival and neurite extension. Viable cells were measured by the MTT colorimetric method. The neurite extension was monitored under a phase-contrast microscope in comparison with that of the control cells.

\section{References}

1) Hefti, F.; J. Hartikka \& B. Knusel: Function of neurotrophic factors in the adult and aging brain and their possible use in the treatment of neurodegenerative diseases. Neurobiology of Aging 10: 515 533, 1989

2) Korsching, S.: The neurotrophic factor concept: A reexamination. J. Neurosci. 13: $2739 \sim 2748,1993$

3) Fischer, W.; K. Wictorin, A. BJorklund, L. R. Williams, S. Varon \& F. H. GaGe: Amelioration of cholinergic neuron atrophy and spatial memory impairment in aged rats by nerve growth factor. Nature 329: 65 68, 1987

4) Williams, L. R.; S. Varon, G. M. Peterson, K. Wictorin, W. Fischer, A. BJorklund \& F. H. GaGe: Continuous infusion of nerve growth factor prevents basal forebrain neuronal death after fimbria fornix transection. Proc. Natl. Acad. Sci. USA 83: 9231 9235,1986 
5) Kromer, L. F.: Nerve growth factor treatment after brain injury prevents neuronal death. Science 235: $214 \sim 216,1987$

6) Shigeno, T.; T. Mima, R. Tokiwa, K. Takakura, S. Furukawa \& D. I. Graham: Intraventricular administration of nerve growth factor prevents the development of delayed neuronal death in the hippocampus. Igaku No Ayumi 145: 579 580, 1988

7) Pollok, J. D.; M. Krempin \& B. Rudy: Differential effects of NGF, FGF, EGF, cAMP, and Dexamethasone on neurite outgrowth and sodium channel expression in PC12 cells. J. Neurosci. 10: $2626 \sim 2637$, 1990

8) Ito, M.; M. Maruhashi, N. Sakai, K. Mizoue \& K. HANADA: NG-011 and NG-012, novel potentiators of nerve growth factor. I. Taxonomy, isolation, and physicochemical and biological properties. J. Antibiotics 45: $1559 \sim 1565,1992$

9) Ito, M.; Y. Tsuchida, K. Mizoue \& K. Hanada: NG-011 and NG-012, novel potentiators of nerve growth factor. II. The structure determination of
NG-011 and NG-012. J. Antibiotics 45: $1566 \sim 1572$, 1992

10) Nozawa, Y.; K. Yamamoto, M. Ito, N. Sakal, K. Mizoue, F. Mizore \& K. Hanada: Stachybotrin C and parvisporin, novel neuritogenic compounds. I. Taxonomy, isolation, physico-chemical and biological properties. J. Antibiotics 50: 635 640, 1997

11) Nozawa, Y.; M. Ito, K. Sugawara, K. Hanada \& K. Mizoue: Stachybotrin $C$ and parvisporin, novel neuritogenic compounds. II. Structure determination. J. Antibiotics 50: 641 645, 1997

12) Raper, K. B.; C. Thom \& D. I. Fennel: A Manual of the Penicillia. Williams. and Wilkins Co., Baltimore, Md., 1949

13) Pitt, J. I.: A Laboratory guide to common Penicillium species. pp. 146 147, CSIRO, 1988

14) Bhadari, R.; T. Eguchi, A. Sekine, Y. Ohashi, K. Kakinuma, M. ITo \& K. Mizone: Structure of NG-061, a novel potentiator of nerve growth factor (NGF) isolated from Penicilium minioluteum F-4627. J. Antibiotics 52: 231 234, 1999 